\title{
CRITICAL PERSPECTIVES IN FORENSIC CARE
}


Also by Tom Mason (with Ann Alty)

SECLUSION AND MENTAL HEALTH

A Break with the Past 


\section{CRITICAL Perspectives in
Forensic Care \\ INSIDE OUT}

Edited by

Tom Mason and Dave Mercer

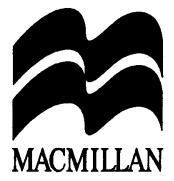


Selection, editorial matter, and Chapters 1, 2 and 9

(C) Tom Mason and Dave Mercer 1998

Other chapters (in order) (C) Dave Mercer, Ged McCann,

Richard Whittington and David Balsamo, Tom Mason and

Mark Chandley, Steven George, Dave Mercer, Joel Richman,

Steve Burrow, Mick McKeown and Mark Stowell-Smith,

Mick McKeown and Dave Mercer, Jane Senior,

Gerry Carton 1998

All rights reserved. No reproduction, copy or transmission of this publication may be made without written permission.

No paragraph of this publication may be reproduced, copied or transmitted save with written permission or in accordance with the provisions of the Copyright, Designs and Patents Act 1988, or under the terms of any licence permitting limited copying issued by the Copyright Licensing Agency, 90 Tottenham Court Road, London W1P 9HE.

Any person who does any unauthorised act in relation to this publication may be liable to criminal prosecution and civil claims for damages.

The authors have asserted their rights to be identified as the authors of this work in accordance with the Copyright, Designs and Patents Act 1988.

First published 1998 by

MACMILLAN PRESS LTD

Houndmills, Basingstoke, Hampshire RG21 6XS

and London

Companies and representatives

throughout the world

ISBN 978-0-333-69311-7 ISBN 978-1-349-26104-8 (eBook)

DOI 10.1007/978-1-349-26104-8

A catalogue record for this book is available from the British Library.

$\begin{array}{llllllllll}10 & 9 & 8 & 7 & 6 & 5 & 4 & 3 & 2 & 1\end{array}$

$\begin{array}{llllllllll}07 & 06 & 05 & 04 & 03 & 02 & 01 & 00 & 99 & 98\end{array}$

Copy-edited and typeset by Povey-Edmondson

Tavistock and Rochdale, England 


\section{CONTENTS}

Preface

vii

Acknowledgements ix

Notes on the Contributors

List of Abbreviations

1 Introduction: The Silent Scream

Tom Mason and Dave Mercer

2 From Devilry to Diagnosis: The Painful Birth of Forensic Psychiatry

Dave Mercer and Tom Mason

3 Beyond Madness and Badness: Where Angels Fear to Tread?

Dave Mercer

4 Control in the Community

Ged McCann

5 Violence: Fear and Power

Richard Whittington and David Balsamo

6 Seclusion: A Catacomb of Control

Tom Mason and Mark Chandley

7 More than a Pound of Flesh: A Patient's Perspective Steven George (pseudonym)

8 The Nature of the Beast: Sex Offender Treatment Dave Mercer

9 Rehabilitation: 'The Ship of Fools'?

Tom Mason and Dave Mercer

10 The Ceremonial and Moral Order of a Ward for Psychopaths Joel Richman 
11 Therapy versus Security: Reconciling Healing and Damnation

Steve Burrow

12 Language, Race and Forensic Psychiatry: Some Dilemmas for Anti-Discriminatory Practice Mick McKeown and Mark Stowell-Smith

13 Fallen from Grace: Women, Power and Knowledge Mick McKeown and Dave Mercer

14 Doctors' Orders: The Mentally Disordered in Prison Jane Senior

15 Nurse Education: Scribes and Scriptures Gerry Carton 


\section{Preface}

Forensic psychiatric nursing is a relatively new branch of nursing under the broader term of mental health care. There are some who hold that it is a new discipline with a unique body of knowledge, albeit uncharted. Others believe that it merely represents generic psychiatric nursing directed towards a specific patient population, that of mentally abnormal offenders. This debate locates forensic psychiatric nursing at a very early stage in its developmental process and suggests that, as yet, we are unclear as to what its constituent parts comprise. A major problem for this inchoate discipline reflects the failure of the profession, generally, critically to analyse theoretical ideas or their pragmatic application. In terms of forensic nursing there has been a reluctance to confront those thorny issues specific to the practice setting. This book is an attempt to address these deficits.

As we began to scratch the surface of an abundance of veneers the sub-title of the book became all important. The medicalisation of the criminal, through institutional power, suggests that the undercurrents to compulsory detention and forced treatment are riven with tensions and dilemmas for those agents of psychiatry. This agency impels forensic psychiatry, and thus nursing, to adopt and extend systems of control and surveillance beyond traditional forensic institutions to the more nebulous services of the community: inside out.

We make no apologies for challenging nursing orthodoxy and confronting belief systems apparently based on little else than faith. Unless we take debates beyond the blinkered thinking of contemporary 'champions' to read a different discourse from the mass production of mission statements, or penetrate the blinding glare of the glossy brochure, we are doomed to produce merely nursing bisspeak. The issues addressed in this book are some of those areas that receive either little critical attention or else are smothered in jargon. This book is an attempt to take these issues from different perspectives and turn them inside out.

This trend towards the forensic field as an expert terrain has witnessed a rapid expansion, or explosion, of courses to meet the 
training needs of practitioners. Too often, though, curriculum content seems to have been sacrificed to market demands. If education is the key to professional integrity, our commitment in this area is to stimulate dialogue both inside and outside of the classroom.

We hope that there will be many readers of this book, from differing professions, who will find the approach appealing and refreshing. It will be a valuable read for all those in mental health care who are concerned about our continuing, and expanding, role in the psychiatrisation of society.

TOM MASON

DAVE MERCER 


\section{ACKNOWLEDGEMENTS}

There are some whose insight has helped us. There are some whose fear has hindered us. There are some whose ignorance has inspired us. All have provided some motivation. Thank you all. 


\section{Notes ON the Contributors}

David Balsamo, BA, MSc, MSc, CQSW, is a Senior Lecturer in Sociology in the Department of Health and Community Studies at University College, Chester. He obtained his first degree at the (former) Middlesex Polytechnic and went on to postgraduate work at the Universities of London and Oxford. He is a qualified social worker and has worked as a probation officer with a special interest in work with sex offenders. His published work has as its focus the relationship of social theory to health, nursing and social work.

Steve Burrow, MA, BSc (Hons), RMN, RGN, Cert.Ed., RNT, has a forensic nursing career which has spanned an intensive care unit, two medium secure units, and two special hospitals in the variable capacities of senior clinician, senior nurse manager, researcher, tutor/lecturer and now nurse adviser to Broadmoor Hospital Authority. $\mathrm{He}$ is also attached to the Institute of Psychiatry as an honourary lecturer and MPhil/PhD student where he is pursuing an evaluation study of forensic nursing. His published research has focused on the self-harming behaviour of special hospital patients as well as a multi-disciplinary study of Special Hospital patients' treatment and security needs. As an editorial board adviser to two professional nursing journals, and as a regular publisher of work on psychiatric nursing issues, he feels that one of his best achievements is his contribution to the public discourse relating to the evolving forensic nursing role.

Gerry Carton, RMN, RNMH, RCNT, Cert.Ed., Cert. Research, Dip. Research, is a Senior Education Manager at Rampton Hospital. He has extensive experience in both psychiatric and mental handicap nursing and has been involved in forensic care for eight years. He is a keen researcher with a number of projects completed, and is an innovator of many educational initiatives in the forensic setting. He has developed strong links with Sheffield Hallam University and teaches at both Rampton and Sheffield.

Mark Chandley, RMN, BA (Hons), has worked in the Special Hospitals for eleven years, both at Moss Side and Park Lane (now 
Ashworth). He is RMN trained and recently completed a degree in Health Studies at BA (Hons) level, bringing theory to a clinical base as a team leader. He works on a crisis intervention, special-care, high-dependency unit, steering the unit through rapid change. He is an experienced researcher, who has also published, most recognisably in the Journal of Advanced Nursing. He is currently researching the relationships of seclusion, medication and restraint, and is an active participant in many nursing initiatives.

Steven George (pseudonym) is a middle-aged man who has been in forensic care within the Special Hospitals since his teens. He is classified as suffering with a psychopathic disorder and is an outspoken critic of compulsory detention of the psychiatric patient.

Tom Mason, RMN, RNMH, RGN, BSc (Hons), PhD, has worked in the Special Hospitals since the mid-1970s at Moss Side, Broadmoor, and Park Lane (the first and the last having now amalgamated to form Ashworth). He has also worked at Barrow Hospital, Bristol; Maudsley and Bethlem Royal Hospital, London; and at King's College Hospital, London. He is a Registered Mental Nurse, Registered Nurse for the Mentally Handicapped, and a Registered General Nurse. He is a BSc (Hons) graduate from Manchester Polytechnic and was awarded a PhD in 1995. He has over 30 publications on diverse nursing issues including a co-authored book Seclusion and Mental Health: A Break with the Past (Chapman and Hall, 1994).

Ged McCann, RMN, DipHE, DPSN (Thorn), BPhil, has also trained as a Registered Mental Nurse at Ashworth Special Hospital where he worked for thirteen years. Whilst at Ashworth he completed further training including the Thorn Diploma in Psychosocial Interventions at Manchester University. Initiatives included the first relative support group in the hospital, and implementing psychoeducation programmes with relatives and patients. He has also been the project leader of a multi-disciplinary research team which evaluated the effects of a psycho-education programme for schizophrenia within a forensic setting. He developed open learning packs for staff in psychosocial interventions and was co-leader of an optional diploma module, 'psychosocial interventions in forensic care and management'. He commenced development of a Forensic Thorn Initiative before leaving Ashworth in 1995. He is presently County Development Officer for Mentally Disordered Offenders in North Yorkshire Health Authority and is also Honorary Lecturer at 
York University as leader of the psychosocial interventions module within the Mental Health Pathways Programme. He has published widely in nursing journals and delivered numerous papers at conferences.

Mick McKeown, RGN, RMN, BA (Hons), DPSN (Thorn), is a mental health nurse working as a lecturer/practitioner between the University of Liverpool and an inner-city rehabilitation service, which incudes a high-dependency unit. Prior to this he was employed for four years in the rehabilitation service of Ashworth Hospital, primarily offering group work. His clinical interests are in meeting the needs of people with severe and enduring mental health problems via psychosocial interventions. To this end he has been involved in a number of practice, staff training and research initiatives. Not divorced from these clinical concerns, he is not alone in viewing nursing and psychiatry as appropriate domains of political activity; hence he has been a UNISON steward for the bulk of his health service career. Of particular interest are the routes by which the seemingly diverse interests of care staff and service users can be realised in ways which are mutually supportive.

Dave Mercer, RMN, BA (Hons), PGCE, MA. currently works as a lecturer-practitioner in the Forensic Practice Development Centre at Ashworth Hospital, where he is Course Director for the Diploma in Forensic Care and Management. His career in mental health nursing embraces both general psychiatry and high security services. With a strong commitment to critical criminological analysis, his research and writing attempts to contextualise clinical concerns within a larger structural framework of politics and power. Particular academic interests around sexuality and pornography are integrated with a practice role in the delivery of sex-offender treatment programmes at Ashworth Hospital. He is currently undertaking a $\mathrm{PhD}$ focused on pornography as a clinical concern in secure settings.

Joel Richman, BA, MA (Econ), PhD, was a founder member of Manchester Polytechnic, now the Manchester Metropolitan University. He was a head of the school of sociology and psychology. Research areas included: the sociology of the street and public space; gynaecology and obstetrics, with emphasis on place of birth, pregnant fathers and language and consultation; psychiatric ward cultures, especially the Special Hospitals. With multi-disciplinary specialists he researched for the National Childbirth Trust. Publications include: Traffic Wardens: An Ethnography of Street Administration 
(Manchester University Press, 1983); Medicine and Health (Longman, 1987); and Health (Macmillan, 1992). Contributions have been made to several edited books and numerous journals. Before retirement he was awarded a chair in medical sociology and anthropology. As emeritus professor he continues to work part-time in the department of Health Care Studies.

Jane Senior, MA, BA (Hons), RMN, commenced her career in mental health nursing, which has increasingly focused on challenging behaviours in a variety of settings, after studying for a first degree in the humanities. Her RMN was undertaken in the Elizabeth Campbell School of Nursing, an experimental venture between Park Lane Special Hospital and Cheadle Royal in Manchester. Since then she has worked in acute admissions and as a member of the healthcare team in a prison establishment for young offenders. Recently she has taken up a post as a community forensic nurse and has completed a higher degree in criminology at Keele University.

Mark Stowell-Smith, PhD, MSc, Dip.PSW, BA, has worked as a forensic social worker at Ashworth Hospital for a number of years. In this time he has been active in developing a range of psychotherapeutic skills, such that his role has changed latterly to become much more therapy orientated. His doctoral studies explored anomalies in the diagnosis and treatment of black people in forensic institutions in relation to the concept of psychopathy. This work specifically raised issues around the social constructions of forensic psychiatry, attendant practices, and ethnographic conceptualisations of the 'self' which operate in racially prejudicial ways.

Richard Whittington, BA, RMN, PhD, C.Psychol, AFBPs, is a Senior Lecturer in Psychology in the Department of Health and Community Studies at University College, Chester, and is also a Chartered Forensic Psychologist. He obtained his first degree in psychology from Manchester University in 1981 and qualified as a psychiatric nurse at St George's Hospital in London in 1986. After two years as a staff nurse and charge nurse on a Psychiatric Intensive Care Unit at the Maudsley Hospital, he conducted research into violence in psychiatric in-patient settings at the Maudsley Hospital and the Institute of Psychiatry, London. He obtained his $\mathrm{PhD}$ in 1992 and has now published widely on issues of violence in psychiatry and other health-care settings with particular focus on applying socialcognitive theories to the causation of aggression and the development of trauma reactions in staff following assault. 


\section{LIST OF ABbREVIATIONS}

AFBPsS Associate Fellow of the British Psychological Society

APA American Psychiatric Association

BJC British Journal of Criminology

CPN Community Psychiatric Nurse

C.Psychol Chartered Psychologist

CQSW Certificate of Qualification in Social Work

DipHE Diploma in Higher Education

DNA Deoxyribonucleic Acid

DPSN Diploma in Professional Studies in Nursing

ENB English National Board

HSPSCB High Security Psychiatric Services Commissioning Board

MHRT Mental Health Review Tribunal

NACRO National Association for the Care and Resettlement of Offenders

NHS National Health Service

PCTM Patient Care Team Meeting

PD Psychopathic Disorder

POA Prison Officers' Association

RCNT Registered Clinical Nurse Tutor

RGN Registered General Nurse

RMN Registered Mental Nurse

RMO Responsible Medical Officer

RNMH Registered Nurse for the Mentally Handicapped

RNT Registered Nurse Teacher

RSU Regional Secure Unit

SHSA Special Hospitals Service Authority 